\title{
The Effect of Titanium Carbonitride on the Viscosity of High-Titanium-Type Blast Furnace Slag
}

\author{
Hongen Xie ${ }^{1,2} \oplus$, Wenzhou $\mathrm{Yu}^{1,3, *}$, Zhixiong You ${ }^{1,3}$, Xuewei $\mathrm{Lv}^{1,3}$ and Chenguang Bai ${ }^{3}$ \\ 1 College of Materials Science and Engineering, Chongqing University, Chongqing 400045, China; \\ pzhxiehongen@163.com (H.X.); youzx@cqu.edu.cn (Z.Y.); lvxuewei@163.com (X.L.) \\ 2 State Key Laboratory of Vanadium and Titanium Resources Comprehensive Utilization, Pangang Group \\ Research Institute Co., Ltd., Panzhihua 617000, China \\ 3 Chongqing Key Laboratory of Vanadium-Titanium Metallurgy and Advanced Materials, Chongqing \\ University, Chongqing 400044, China; bguang@cqu.edu.cn \\ * Correspondence: yuwenzhoucd@cqu.edu.cn; Tel.: +86-23-6511-2631
}

Received: 8 March 2019; Accepted: 27 March 2019; Published: 30 March 2019

\begin{abstract}
In this paper, the effect of titanium carbonitride $(\mathrm{Ti}(\mathrm{C}, \mathrm{N}))$ on the viscosity of high-titanium-type blast furnace slags was investigated. The different $\operatorname{Ti}(\mathrm{C}, \mathrm{N})$ contents were achieved by adjusting the reduction degree of $\mathrm{TiO}_{2}$ to reflect the real characteristics of the high-titanium slag. The results show that the viscosity of the slag increased with the increasing $\operatorname{Ti}(\mathrm{C}, \mathrm{N})$ content and decreased with the rising temperature. A deviation between the measured and the fitted viscosity appeared as the content of the $\operatorname{Ti}(\mathrm{C}, \mathrm{N})$ was beyond $4 \mathrm{wt} \%$. Furthermore, the apparent viscous flow activation energy of the slag ranged from $106.13 \mathrm{~kJ} / \mathrm{mol}$ to $235.46 \mathrm{~kJ} / \mathrm{mol}$ by varying the $\mathrm{Ti}(\mathrm{C}, \mathrm{N})$ contents from $0 \mathrm{wt} \%$ to $4.97 \mathrm{wt} \%$, which was evidently different from the results of previous studies. The optical microscope and energy dispersive X-ray spectroscopy (EDS) analysis show that numerous bubble cavities were embedded in the slags and the $\mathrm{Ti}(\mathrm{C}, \mathrm{N})$ particles agglomerated in the solidified samples. This phenomenon further indicates that the high-titanium slag is a polyphase dispersion system, which consists of liquid slag, solid $\mathrm{Ti}(\mathrm{C}, \mathrm{N})$ particles and bubbles.
\end{abstract}

Keywords: blast furnace slag; $\mathrm{TiO}_{2}$; titanium carbonitride; viscosity

\section{Introduction}

Viscosity of $\mathrm{TiO}_{2}$-containing slags is an important factor influencing the processes of ironmaking, steelmaking and Ti-recycling industries [1-3]. The content of titania $\left(\mathrm{TiO}_{2}\right)$ in high-titanium-type blast furnace slag is always more than $20 \mathrm{wt} \%$. Therefore, it is inevitable that part of the $\mathrm{TiO}_{2}$ in this slag was reduced to titanium carbonitride $(\mathrm{Ti}(\mathrm{C}, \mathrm{N}))$ particles by coke during blast furnace production. The $\operatorname{Ti}(\mathrm{C}, \mathrm{N})$ particle is harmful for the fluidity of the slag because it has a high melting point and can significantly increase the viscosity of the slag. According to Einstein's theory [4] about the relation between the volume fraction of solid particles and the viscosity of extremely dilute solutions, Roscoe presented a type of equation (Einstein-Roscoe type equation) to describe the viscosity of liquids containing high concentrations of solid suspensions [5]:

$$
\eta=\eta_{0}(1-a f)^{-n}
$$

where $\eta$ and $\eta_{0}$ are the viscosity of solid-containing and solid-free liquid, respectively; $f$ is the volume fraction of solid particles in the liquid; $a$ and $n$ are constants with regard to the volume fraction and geometrical shape of solid particles in liquid, and are 1.35 and 2.5 for spherical particles with a uniform size, respectively. This equation indicates that the viscosity of the melt should be related to 
the volume fraction and geometrical shape of solid particles in liquid. To explore this relationship in metallurgical slags, some research has been carried out by adding small amounts of solid particles to the slags. Wright et al. [6] studied the viscosities of $\mathrm{CaO}-\mathrm{MgO}-\mathrm{Al}_{2} \mathrm{O}_{3}-\mathrm{SiO}_{2}$ melts containing spinels with different sizes at $1646 \mathrm{~K}$; Liu et al. [7] studied the effect of $\mathrm{Ti}\left(\mathrm{C}_{0.3} \mathrm{~N}_{0.7}\right)$ particles of $1.0 \mu \mathrm{m}$ on the viscosities of $\mathrm{CaO}-\mathrm{MgO}-\mathrm{Al}_{2} \mathrm{O}_{3}-\mathrm{SiO}_{2}$ blast furnace slag and $\mathrm{Zhen} \mathrm{et} \mathrm{al.} \mathrm{[8]} \mathrm{discussed} \mathrm{the} \mathrm{effect} \mathrm{of} \mathrm{TiC}$ particles on the viscosity of $\mathrm{CaO}-\mathrm{MgO}-\mathrm{Al}_{2} \mathrm{O}_{3}-\mathrm{SiO}_{2}-\mathrm{TiO}_{2}$ slag. Their results suggested that the viscosity of the solid-containing melt increased with the addition of particles, and the Einstein-Roscoe type equation can well describe the viscosity variation behavior by allowing the parameters $a$ and $n$ to vary. To investigate the flow behavior of high-titanium-type slag, Jiang et al. [9] studied the effect of TiC solid particles on the rheological behavior of blast furnace slags with $20 \mathrm{wt} \%$ of total $\mathrm{TiO}_{2}$ and Yue et al. [10] discussed the rheological behavior of Ti-bearing blast furnace slag with different TiN contents. Both of them pointed out that the slags will convert to non-Newtonian fluids if the volume fraction of the solid particles beyond certain values and the Einstein-Roscoe type equation could be not suitable at that condition.

In the last few decades, a large amount of research [11-19] has attempted to establish an accurate description about the viscosity of the high-titanium-type slag and a lot of fruitful achievements have been obtained. However, the existing empirical and semi-empirical models still cannot describe the viscosity precisely. One of the possible reasons for this may be the improper method for preparing the experimental slag. For example, most of the previous studies prepared the high-titanium-type slag by adding the solid particles directly to the $\mathrm{TiO}_{2}$-containing slags. However, this could not be enough to reflect the real characteristics of the on-site slag (slag in blast furnace). The morphology and distribution of $\mathrm{TiC}, \mathrm{TiN}$, and $\mathrm{Ti}(\mathrm{C}, \mathrm{N})$ in on-site slag should be different from those directly added to the slag. Additionally, on-site slag is also different from the slag prepared by high purity reagents because there are some gas bubbles in on-site slag, which makes the structure of molten slag more complicated. Up to now, there is still a lack of accurate knowledge of viscosity properties for the high-titanium-type blast furnace slag. In order to control the iron-making process of titanium-vanadium-magnetite more efficiently, a further understanding of flow behaviors in high-titanium-type blast furnace slag should be necessary.

In the present study, to discuss the effect of titanium carbonitride on the viscosity of the high-titanium-type blast furnace slag, on-site slags with different contents of titanium carbonitride (reduced from $\mathrm{TiO}_{2}$ ) were prepared. Additionally, the viscosities of these slags were measured to clarify the relationships between slag fluidity and the contents of titanium carbonitride.

\section{Materials and Methods}

On-site blast furnace slags were used as the raw materials in the experiment. The residual metal iron in the slag was removed by magnetic separation, and then the slag was crushed to less than 0.1 $\mathrm{mm}$. The chemical compositions of the slags were analyzed by X-ray fluorescence spectrometry (XRF, Shimadzu XRF-1800, Kyoto, Japan), as shown in Table 1. Coke was employed as the reductive agent for reducing the $\mathrm{TiO}_{2}$ to $\mathrm{Ti}(\mathrm{C}, \mathrm{N})$ in the experiment (compositions are shown in Table 2), which the particle size was controlled between $10 \mathrm{~mm}$ and $15 \mathrm{~mm}$.

Table 1. Chemical compositions of on-site slag, mass $\%$.

\begin{tabular}{ccccccc}
\hline $\mathrm{CaO}$ & $\mathrm{SiO}_{2}$ & $\mathrm{MgO}$ & $\mathrm{Al}_{\mathbf{2}} \mathrm{O}_{3}$ & $\mathrm{TiO}_{2}$ & $\mathrm{TiC}$ & $\mathrm{TiN}$ \\
\hline 25.12 & 24.63 & 9.50 & 14.00 & 22.50 & 0.49 & 0.50 \\
\hline
\end{tabular}

Table 2. Chemical compositions of the coke, mass $\%$.

\begin{tabular}{ccccccccc}
\hline FCad & St & Vadf & Ad & $\mathbf{C a O}$ & $\mathbf{S i O}_{2}$ & $\mathbf{M g O}$ & $\mathbf{A l}_{2} \mathbf{O}_{3}$ & $\mathbf{F e}_{2} \mathbf{O}_{3}$ \\
\hline 86.26 & 0.54 & 1.23 & 12.67 & 0.49 & 7.01 & 0.20 & 3.05 & 0.95 \\
\hline
\end{tabular}


A muffle furnace (Teenpu CO. LTD., Jiangyin, China) was used to prepare experimental slags with different $\mathrm{Ti}(\mathrm{C}, \mathrm{N})$ contents. The experimental schematic diagram is shown in Figure 1 . The heating element is a U-shaped silicon molybdenum rod, the heating process is controlled by PID (Proportion Integral Differential) program, and the temperature is measured by a B-type thermocouple. About $140 \mathrm{~g}$ coke was firstly placed in a graphite crucible (52 $\mathrm{mm}$ inner diameter, $160 \mathrm{~mm}$ length), and about $210 \mathrm{~g}$ slag was placed on the top of the coke. The graphite crucible was then put into a larger corundum crucible to reduce the oxidation degree of the graphite crucible during the experiment. The temperature of the chamber increased to $1773 \mathrm{~K}$ at $10 \mathrm{~K} / \mathrm{min}$, and then held for $15 \mathrm{~min}, 30$ $\mathrm{min}, 45 \mathrm{~min}$ and $60 \mathrm{~min}$, respectively. After that, the samples were cooled down together with the furnace. The residual cokes in the slags were separated using a hammer and cleaned up by hairbrush. The obtained slags (experimental slags) were crushed to less than $0.1 \mathrm{~mm}$, some of which was used to analyze the chemical composition, and the rest was used to measure the viscosity. The contents of $\mathrm{TiC}$ and $\mathrm{TiN}$ in the experimental slags were obtained by chemical analysis, and the results are shown in Table 3. The content of $\mathrm{Ti}(\mathrm{C}, \mathrm{N})$ could not be obtained directly by chemical analysis, thus it was represented by the total contents of TiC and TiN. Number 1 in Table 3 indicates the raw slag without reduction by coke, which the content of $\operatorname{Ti}(\mathrm{C}, \mathrm{N})$ was $0.99 \%$. The $\mathrm{Ti}(\mathrm{C}, \mathrm{N})$-free slag was obtained by roasting the raw slag at $1573 \mathrm{~K}$ for $60 \mathrm{~min}$, as represented by 0 in Table 3 . The contents of TiC and TiN in this slag were lower than 0.001 mass $\%$, respectively. In order to further confirm the composition of the morphology in the slag, a microstructure analysis was carried out by using the optical microscope (OLYMPUS BX51, Hatagaya, Japan) and scanning electron microscopy with energy dispersive X-ray spectroscopy (SEM-EDS) (FEI, Hillsboro, OR, USA), and the results are shown in Figure 2 and Table 4.

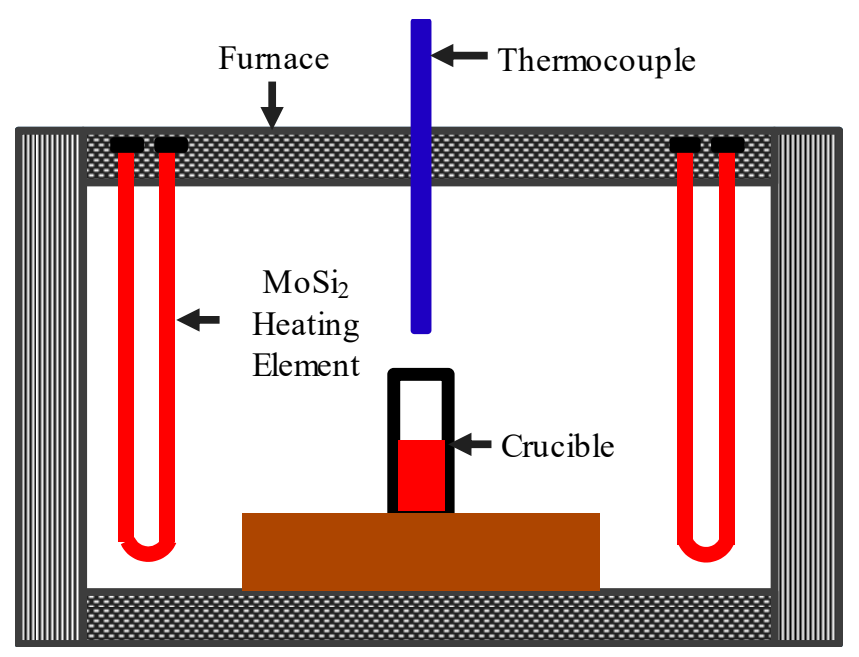

Figure 1. Schematic diagram of the muffle furnace.

Table 3. The contents of $\mathrm{TiC}$ and $\mathrm{TiN}$ in experimental slags, mass $\%$.

\begin{tabular}{ccccc}
\hline Samples & Time/min & TiC & TiN & Ti(C,N) \\
\hline 0 & - & $<0.001$ & $<0.001$ & 0 \\
1 & - & 0.49 & 0.50 & 0.99 \\
2 & 15 & 1.08 & 1.09 & 2.17 \\
3 & 30 & 1.79 & 1.55 & 3.34 \\
4 & 45 & 2.01 & 2.04 & 4.05 \\
5 & 60 & 2.16 & 2.81 & 4.97 \\
\hline
\end{tabular}




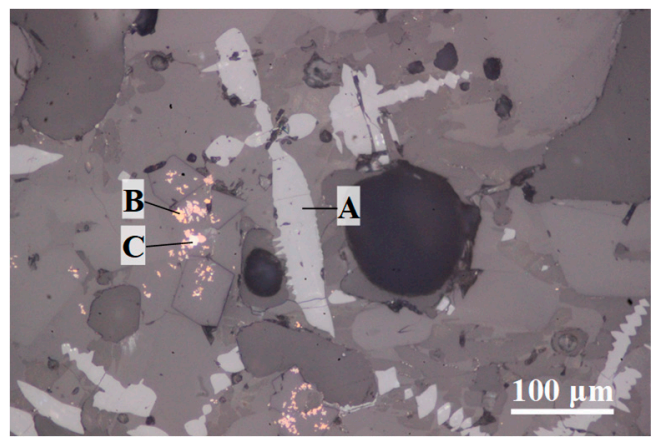

Figure 2. Microstructure of the slag sample (A is Perovskite, B is Tianium carbonitride, C is metal iron.).

Table 4. Energy dispersive X-ray spectroscopy (EDS) analysis of the points in Figure 2, mass\%.

\begin{tabular}{ccccccc}
\hline Points & C & N & O & Ca & Ti & Fe \\
\hline Point A & - & - & 34.75 & 29.33 & 35.92 & - \\
Point B & 10.77 & 5.94 & - & - & 83.29 & - \\
Point C & - & - & - & - & - & 100.0 \\
\hline
\end{tabular}

The EDS (EDAX, Mahwah, NJ, USA) analysis (Table 4) shows that lots of brick-red Ti(C,N) particles were produced in the slag. Additionally, the white iron phase and the grey/white perovskite phase were also observed in the slag.

A schematic diagram of the viscosity measurement apparatus is shown in Figure 3, which includes a Brookfield digital viscometer, a heating system, an automatic lifting system, a temperature control system, and a gas supply system. The heating element is a U-shaped $\mathrm{MoSi}_{2}$ rod, which has a maximum working temperature of $1923 \mathrm{~K}$. The inner diameter of the high purity alundum tube of the shaft furnace is $55 \mathrm{~mm}$, and the height of the constant temperature zone is about $60 \mathrm{~mm}$. The temperature is controlled by PID program, and temperature is measured by a B-type thermocouple with Pt- 6 wt pct $\mathrm{Rh} / \mathrm{Pt}-30$ wt pct $\mathrm{Rh}$. Argon gas with a purity of $99.99 \%$ was employed as the protection gas. During the experiment, the argon gas flowed in from the bottom of the alundum tube and flowed out from the top, and the gas flow was maintained at $1.5 \mathrm{~L} / \mathrm{min}$.

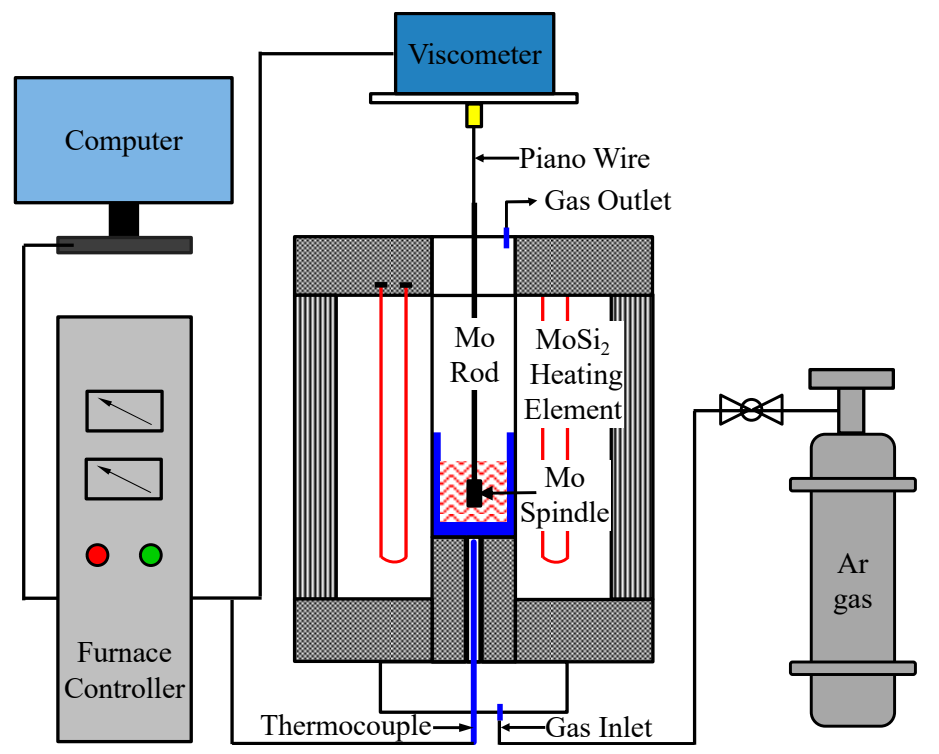

Figure 3. Schematic diagram of the viscosity measurement apparatus.

The viscosity of experimental slag was measured by the rotating-cylinder method. About $170 \mathrm{~g}$ experimental slag was put into a high purity graphite crucible $(50 \mathrm{~mm}$ outer diameter, $40 \mathrm{~mm}$ inner 
diameter, $120 \mathrm{~mm}$ length). A metal molybdenum sheet with a thickness of $0.01 \mathrm{~mm}$ was put closely inside the graphite crucle to avoid the reaction between slag and graphite. This graphite crucible was put into another larger graphite crucible (62 mm outer diameter, $52 \mathrm{~mm}$ inner diameter, $160 \mathrm{~mm}$ length) to prevent slag from spilling to damage the alundum tube. The molybdenum spindle (15 mm diameter and $20 \mathrm{~mm}$ height) was connected with a molybdenum rod (5 mm diameter and $475 \mathrm{~mm} \mathrm{length),}$ which linked with the viscometer by a piano wire (carbon spring steel wire). After the molybdenum spindle was slowly immersed into the slag to the predetermined depth, the total height of the liquid slag was about $50 \mathrm{~mm}$. The viscometer was calibrated using three kinds of standard liquids, of which the viscosities were $222.41 \mathrm{mPa} \cdot \mathrm{s}, 528.20 \mathrm{mPa} \cdot \mathrm{s}$ and $1073.3 \mathrm{mPa} \cdot \mathrm{s}$ at $293 \mathrm{~K}$ respectively. The viscosity was measured when the temperature reached $1773 \mathrm{~K}$. The rotation speed of the spindle was controlled at $12 \mathrm{r} / \mathrm{min}$. The measurement time was $30 \mathrm{~min}$ and two viscosity data were obtained per minute, and the average value of measured data was regarded as the viscosity. After the measurement at $1773 \mathrm{~K}$, the temperature was decreased to $1733 \mathrm{~K}, 1693 \mathrm{~K}$ and $1653 \mathrm{~K}$, respectively, and the viscosity at these temperatures was measured by the similar methods.

\section{Results and Discussion}

\subsection{Effect of $\mathrm{Ti}(\mathrm{C}, \mathrm{N})$ on Viscosity of High-Titanium-Type Blast Furnace Slags}

The viscosities of the slags are shown in Table 5. It can be seen that the viscosities of the slags increased as temperature decreased. Simultaneously, with the increase of $\mathrm{Ti}(\mathrm{C}, \mathrm{N})$ content at the same temperature, the viscosities of the slags increased gradually. This indicates that the viscosity of high-titanium-type blast furnace slags can be influenced not only by temperature, but also by the content of $\operatorname{Ti}(\mathrm{C}, \mathrm{N})$ particles.

Table 5. Viscosities of the slags, Pa.s.

\begin{tabular}{ccccc}
\hline Samples & $\mathbf{1 6 5 3} \mathbf{K}$ & $\mathbf{1 6 9 3} \mathbf{K}$ & $\mathbf{1 7 3 3} \mathbf{K}$ & $\mathbf{1 7 7 3} \mathbf{K}$ \\
\hline 0 & 0.194 & 0.166 & 0.145 & 0.123 \\
1 & 0.289 & 0.233 & 0.201 & 0.170 \\
2 & 0.570 & 0.391 & 0.324 & 0.272 \\
3 & 1.052 & 0.656 & 0.553 & 0.452 \\
4 & 1.794 & 1.170 & 0.927 & 0.783 \\
5 & 3.178 & 1.489 & 1.233 & 1.017 \\
\hline
\end{tabular}

In the blast furnace ironmaking process of titanium-vanadium-magnetite, it is inevitable that a lot of $\operatorname{Ti}(\mathrm{C}, \mathrm{N})$ particles are produced. When the $\operatorname{Ti}(\mathrm{C}, \mathrm{N})$ particles enter the slag, the viscosity of the high-titanium-type blast furnace slag will be influenced significantly. By modifying $a$ and $n$ in Equation (1), or only $a$ and fixed $n$, the dependence of the measured viscosity on the content of the solid particles could be described by the Einstein-Roscoe type equation. The constant $n$ is related to the geometrical particle shape and can be assumed to be 2.5 for spherical solid particles. The reciprocal value of $a$ represents the maximum amount of solid $\left(f_{\max }\right)$ that the melt could accommodate before the viscosity becomes "infinite". By fitting the measured values using the Einstein-Roscoe type equation, the values of $a$ can be optimized and the maximum amount of solid $\left(f_{\max }\right)$ can be obtained, and the results are shown in Table 6. The measured and fitted viscosities of the slags are shown in Figure 4.

Table 6. Values for parameters $a, f_{\max }$ and apparent volume fraction at different temperatures.

\begin{tabular}{ccccc}
\hline Parameters & $\mathbf{1 6 5 3} \mathbf{K}$ & $\mathbf{1 6 9 3} \mathbf{K}$ & $\mathbf{1 7 3 3} \mathbf{K}$ & $\mathbf{1 7 7 3} \mathbf{K}$ \\
\hline$n$ & 2.5 & 2.5 & 2.5 & 2.5 \\
$a$ & 13.79 & 12.25 & 12.02 & 11.93 \\
$f_{\max }$ & 0.072 & 0.082 & 0.083 & 0.084 \\
\hline
\end{tabular}




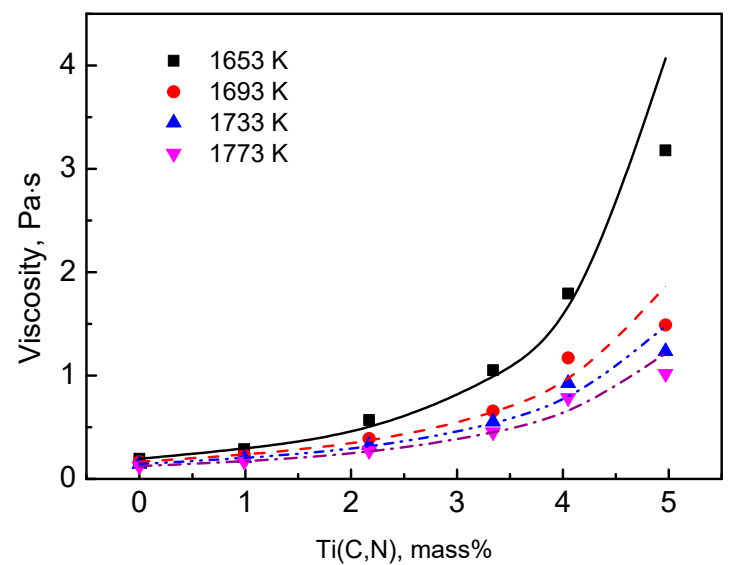

Figure 4. The measured (scattered points) and fitted (lines) viscosities vs. the content of $\mathrm{Ti}(\mathrm{C}, \mathrm{N})$.

It can be seen from Figure 4 that the higher the content of $\mathrm{Ti}(\mathrm{C}, \mathrm{N})$ in the slag, the greater the deviation between the fitted viscosity and the measured viscosity. This becomes obvious when the content of $\operatorname{Ti}(\mathrm{C}, \mathrm{N})$ was over $4 \mathrm{wt} \%$. The main reason for this phenomenon is that the molten slag changed to a non-Newtonian fluid and a shear thinning behavior appeared as the content of the solid particles rose beyond a certain value [9]. It was found from Table 6 that the values of the maximum volume fraction of solids $\left(f_{\max }\right)$ in this study should be significantly lower than that in the studies of Liu [7] and Zhen [8]. The possible reason for this is that the rotation speed of the spindle in this study $(12 \mathrm{r} / \mathrm{min})$ was lower than that used in the other studies (>100 $\mathrm{r} / \mathrm{min})$.

However, in addition to the content of $\operatorname{Ti}(\mathrm{C}, \mathrm{N})$, the influence of bubbles on the viscosity of the on-site slag should not be ignored. It is well known that the smelting of high-titanium-type blast furnace slag can always be accompanied with the formation of bubbles (foam slag). If there are too many bubbles in the molten slag, even if the content of titanium carbonitride is low, the viscosity of the slag will be high [20]. In most cases, the bubbles in the slag were not enough to turn the slag into foam slag. However, there are always more or less bubbles in the slag. The high-titanium-type blast furnace slag should be regarded as a polyphase dispersion system, which consists of liquid slag, solid $\mathrm{Ti}(\mathrm{C}, \mathrm{N})$ particles, and bubbles. When the foam characteristic value was less than 0.74 , the viscosity of the foam can be expressed as [21]:

$$
\eta=\eta_{0}(1+4.5 \Phi)
$$

where $\eta_{0}$ is the viscosity of foam-free liquid and $\Phi$ is the foam characteristic value.

Figure 5 shows the microstructure of the solidified slag. It demonstrated that some micro bubble cavities were embedded in the slag, which proves that the bubbles can stably exist in the slag even though the slag is cooled down. This may be another reason that the deviation between the measured viscosity and the fitted viscosity by Einstein-Roscoe type equation.

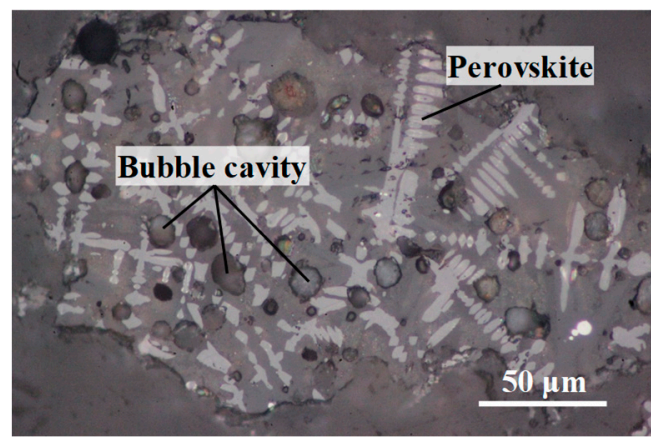

Figure 5. Optical micrograph of the bubble cavity in slag. 


\subsection{The Effect of Ti(C,N) on the Apparent Viscous Flow Activation Energy $E_{\eta}$}

The relation between the viscosity of slag and the temperature was usually expressed by Weymann-Frenkel's equation [22]:

$$
\eta=A \cdot T \cdot \exp \left(E_{\eta} /(R T)\right)
$$

where $A$ is a proportionality constant, $E_{\eta}$ is the apparent activation energy for viscous flow, $R$ is the gas constant and $T$ is the absolute temperature.

According to Equation (3), the curve representing the relationship of $\ln (\eta / T)-10^{5} / T$ is shown in Figure 6 . The scattered points are the measured results, and the lines are the fitted results according to Weymann-Frenkel equation. It can be seen that the relationships between $\ln (\eta / T)$ and $10^{5} / \mathrm{T}$ of slags 0 and 1 were almost completely linear, while those for slags 2 to 5 were gradually deviated from the Weymann-Frenkel equation. When the temperature decreased from $1693 \mathrm{~K}$ to $1653 \mathrm{~K}$, the differences between the measured values and the fitted values were even greater.

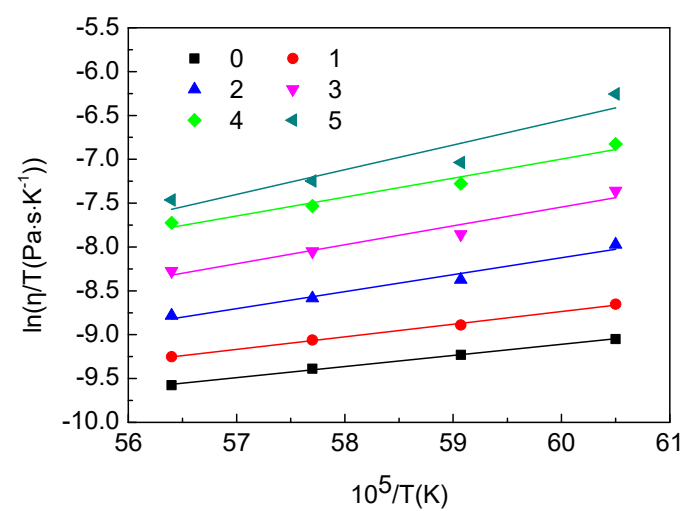

Figure 6. Relationships between $\ln (\eta / \mathrm{T})$ and $10^{5} / \mathrm{T}$ of slags 0 through 5 .

The apparent viscous flow activation energies at different contents of titanium carbonitride are shown in Table 7. As the content of titanium carbonitride increases, the apparent viscous flow activation energy increased significantly. This is different from the results of Zhen et al. [8], which showed the apparent viscous flow activation energy experienced no change with increases in the volume fraction of solid particles. It is well known that the apparent activation energy represents the frictional resistance for viscous flow. In Zhen's [8] study, the solid particles were added to the slag, and the interaction between the solid and the slag should be weak. Thus, they suggested that the composition of liquid slag should be the main factor affecting the activation energy of a suspension system. However, in our study, the $\mathrm{Ti}(\mathrm{C}, \mathrm{N})$ particles in the slag were produced by reducing $\mathrm{TiO}_{2}$, and thus the interaction between the solid and the slag should be strong. The strong interaction can result in a more complicated structure in the real slag. Therefore, much more energy should be required to overcome the viscous fluid activation energy as the content of $\operatorname{Ti}(\mathrm{C}, \mathrm{N})$ particles increases.

Table 7. Apparent viscous flow activation energy at different total contents of $\mathrm{Ti}(\mathrm{C}, \mathrm{N}), \mathrm{kJ} / \mathrm{mol}$.

\begin{tabular}{ccccccc}
\hline Parameters & $\mathbf{0}$ & $\mathbf{1}$ & $\mathbf{2}$ & $\mathbf{3}$ & $\mathbf{4}$ & $\mathbf{5}$ \\
\hline$E_{\eta}, \mathrm{kJ} / \mathrm{mol}$ & 106.13 & 120.30 & 161.41 & 179.73 & 180.61 & 235.49 \\
Adjusted R-Square & 0.9978 & 0.9953 & 0.9605 & 0.9329 & 0.9527 & 0.8440 \\
\hline
\end{tabular}

\subsection{The Distribution of $T i(C, N)$ in Slag}

Figures 7-9 show the microstructures of slag samples quenched in different ways (cooling with liquid nitrogen, water cooling, and natural cooling, respectively). The microstructure was analyzed using the optical microscope (OLYMPUS BX51, Tokyo, Japan) and the phase composition 
was confirmed by SEM-EDS. It can be seen that the perovskite phase, metal iron and $\mathrm{Ti}(\mathrm{C}, \mathrm{N})$ particles were observed in the solidified samples. It is well known that the perovskite phase has a high melting point and can precipitate preferentially from the melt during the cooling process. When decreasing the cooling rate, the crystal size of the perovskite gradually increased, as shown in Figures 7-9. Additionally, a significant agglomeration of $\mathrm{Ti}(\mathrm{C}, \mathrm{N})$ particles were seen in the slag no matter which cooling methods were adopted. As compared to the samples of water cooling and cooling with liquid nitrogen, the agglomeration of $\operatorname{Ti}(\mathrm{C}, \mathrm{N})$ particles was more serious in the natural cooling samples. The solid particles adhered together to form the large agglomeration area. The distribution of titanium carbonitrides in this study were evidently different from those works of Liu, Zhen and Wright et al. [6-8], in which solid particles were evenly distributed in the slag. This implies that the properties of the real slag differs from that of synthetic slag. Additionally, it can be seen in Figures 7-9 that the observed $\operatorname{Ti}(\mathrm{C}, \mathrm{N})$ particles were always adhered with the embedded metallic iron in the slag. The main reason for this phenomenon is that the $\mathrm{TiO}_{2}$ in the slag can react with the carbon dissolved in the metallic iron. This also proves that the high-titanium-type blast furnace slag has a complicated structure and the $\operatorname{Ti}(\mathrm{C}, \mathrm{N})$ particles have a strong interaction with the slag, which should be the main influence on the viscosity of the slag.

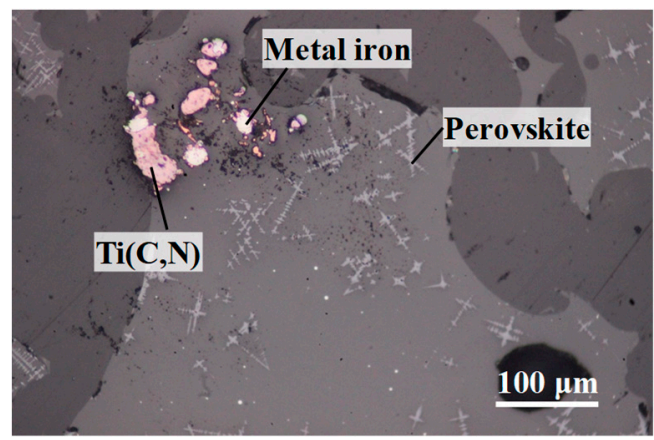

Figure 7. Microstructure of slag sample quenched in liquid nitrogen.

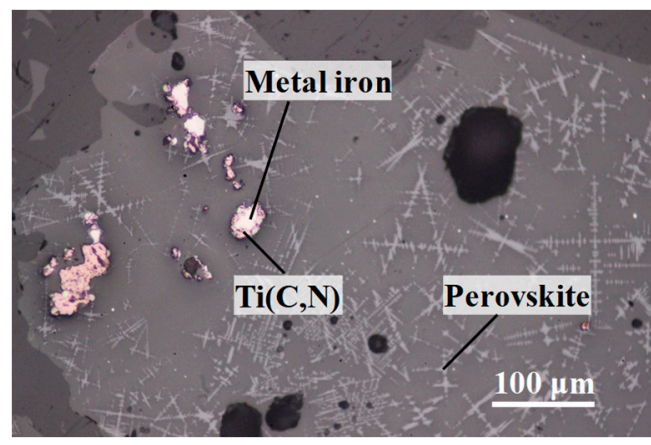

Figure 8. Microstructure of slag sample quenched by water cooling.

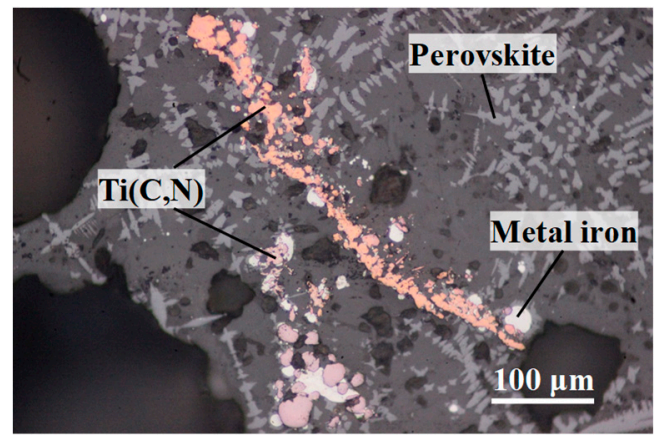

Figure 9. Microstructure of slag sample quenched by natural cooling. 


\section{Conclusions}

This study investigated the viscosity characteristics of high-titanium-type blast furnace slags. Slag samples containing different contents of $\operatorname{Ti}(\mathrm{C}, \mathrm{N})$ particles were prepared, and the influences of $\operatorname{Ti}(\mathrm{C}, \mathrm{N})$ on the viscosity of the slag were studied in detail. The main findings can be summarized as follows:

(1) When increasing the content of $\mathrm{Ti}(\mathrm{C}, \mathrm{N})$, the viscosity of slag samples gradually increased. The measured viscosity and the fitted value by Einstein-Roscoe type equation deviated gradually as the content of $\operatorname{Ti}(\mathrm{C}, \mathrm{N})$ increased. Additionally, the apparent viscous flow activation energy of the slag also increased with increasing the content of $\operatorname{Ti}(\mathrm{C}, \mathrm{N})$.

(2) Microbubbles can exist in the slag stably and a serious agglomeration of $\operatorname{Ti}(\mathrm{C}, \mathrm{N})$ particles was observed in the slag samples. Thus, the high-titanium-type blast furnace slag is actually a polyphase dispersion system, which consists of liquid slag, solid Ti $(\mathrm{C}, \mathrm{N})$ particles, and bubbles.

Author Contributions: Conceptualization, W.Y.; Methodology, W.Y.; Software, H.X.; Validation, H.X., W.Y., Z.Y. and C.B.; Formal Analysis, W.Y. and X.L.; Investigation, H.X. and Z.Y.; Resources, W.Y.; Data Curation, W.Y.; Writing-Original Draft Preparation, H.X.; Writing-Review and Editing, W.Y.; Visualization, W.Y.; Supervision, W.Y.; Project Administration, W.Y.; Funding Acquisition, W.Y.

Funding: This research was funded by the National Natural Science Foundation of China (grant number: 51674053, 51704053) and the Fundamental Research Funds for the Key Universities (grant number: 2018CDJDCL0021).

Conflicts of Interest: The authors declare no conflict of interest.

\section{References}

1. $\mathrm{Hu}, \mathrm{K} . ; \mathrm{Lv}, \mathrm{X} . W . ; \mathrm{Li}$, S.P.; Lv, W.; Song, B.; Han, K.X. Viscosity of $\mathrm{TiO}_{2}-\mathrm{FeO}-\mathrm{Ti}_{2} \mathrm{O}_{3}-\mathrm{SiO}_{2}-\mathrm{MgO}-\mathrm{CaO}-\mathrm{Al}_{2} \mathrm{O}_{3}$ for high-titania slag smelting process. Metall. Mater. Trans. B 2018, 49, 1963-1973. [CrossRef]

2. Wang, Z.J.; Sun, Y.Q.; Sridrar, S.; Zhang, M.; Zhang, Z.T. Investigation on viscosity and nonisothermal crystallization behavior of $\mathrm{P}$-bearing steelmaking slags with varying $\mathrm{TiO}_{2}$ content. Metall. Mater. Trans. $B$ 2017, 48, 527-537. [CrossRef]

3. Yang, J.G.; Park, J.H. Distribution behavior of aluminum and titanium between nickel-based alloys and molten slags in the electro slag remelting (ESR) process. Metall. Mater. Trans. B 2017, 48, 2147-2156. [CrossRef]

4. Einstein, A. Investigations on the Theory of the Brownian Movement; Dover Publications, Inc.: New York, NY, USA, 1959.

5. Roscoe, R. The viscosity of suspensions of rigid spheres. Br. J. Appl. Phys. 1952, 3, 267-269. [CrossRef]

6. Wright, S.; Zhang, L.; Sun, S.; Jahanshahi, S. Viscosity of a $\mathrm{CaO}-\mathrm{MgO}-\mathrm{Al}_{2} \mathrm{O}_{3}-\mathrm{SiO}_{2}$ melt containing spinel particles at 1646 K. Metall. Mater. Trans. B 2000, 31, 97-104. [CrossRef]

7. Liu, Y.X.; Zhang, J.L.; Zhang, G.H.; Jiao, K.X.; Chou, K.C. Influence of $\operatorname{Ti}\left(\mathrm{C}_{0.3} \mathrm{~N}_{0.7}\right)$ on viscosity of blast furnace slags. Ironmak. Steelmak. 2017, 44, 608-618. [CrossRef]

8. Zhen, Y.L.; Zhang, G.H.; Chou, K.C. Viscosity of $\mathrm{CaO}-\mathrm{MgO}-\mathrm{Al}_{2} \mathrm{O}_{3}-\mathrm{SiO}_{2}-\mathrm{TiO}_{2}$ melts containing TiC particles. Metall. Mater. Trans. B 2014, 46, 155-161. [CrossRef]

9. Jiang, T.; Liao, D.M.; Zhou, M.; Zhang, Q.Y.; Yue, H.R.; Yang, S.T.; Duan, P.N.; Xue, X.X. Rheological behavior and constitutive equations of heterogeneous titanium-bearing molten slag. Int. J. Miner. Metall. Mater. 2015, 22, 804-810. [CrossRef]

10. Yue, H.R.; He, Z.W.; Jiang, T.; Duan, P.L.; Xue, X.X. Rheological evolution of Ti-bearing slag with different volume fractions of TiN. Metall. Mater. Trans. B 2018, 49, 2118-2127. [CrossRef]

11. Zhang, L.; Zhang, L.N.; Wang, M.Y.; Lou, T.P.; Sui, Z.T.; Jang, J.S. Effect of perovskite phase precipitation on viscosity of Ti-bearing blast furnace slag under the dynamic oxidation condition. J. Non-Cryst. Solids 2006, 352, 123-129. [CrossRef]

12. Yue, H.R.; Jiang, T.; Zhang, Q.Y.; Duan, P.N.; Xue, X.X. Electrorheological effect of Ti-bearing blast furnace slag with different $\mathrm{TiC}$ contents at $1500{ }^{\circ} \mathrm{C}$. Int. J. Miner. Metall. Mater. 2017, 24, 768-775. [CrossRef]

13. Zheng, K.; Zhang, Z.T.; Liu, L.L.; Wang, X.D. Investigation of the viscosity and structural properties of $\mathrm{CaO}-\mathrm{SiO}_{2}-\mathrm{TiO}_{2}$ Slags. Metall. Mater. Trans. B 2014, 45, 1389-1397. [CrossRef]

14. Morizane, Y.; Ozturk, B.; Fruehan, R.J. Thermodynamics of $\mathrm{TiO}_{\mathrm{x}}$ in blast furnace-type slags. Metall. Mater. Trans. B 1999, 30, 29-43. [CrossRef] 
15. Liao, J.L.; Li, J.; Wang, X.D.; Zhang, Z.T. Influence of $\mathrm{TiO}_{2}$ and basicity on viscosity of Ti bearing slag. Ironmak. Steelmak. 2012, 39, 133-139. [CrossRef]

16. Sohn, I.; Min, D.J. A review of the relationship between viscosity and the structure of calcium-silicate-based slags in ironmaking. Steel Res. Int. 2012, 83, 611-630. [CrossRef]

17. Gao, Y.H.; Bian, L.T.; Liang, Z.Y. Influence of $\mathrm{B}_{2} \mathrm{O}_{3}$ and $\mathrm{TiO}_{2}$ on viscosity of titanium-bearing blast furnace slag. Steel Res. Int. 2015, 86, 386-390. [CrossRef]

18. Park, H.; Park, J.Y.; Kim, G.H.; Sohn, I. Effect of $\mathrm{TiO}_{2}$ on the viscosity and slag structure in blast furnace type slags. Steel Res. Int. 2012, 83, 150-156. [CrossRef]

19. Xi, F.S.; Li, S.Y.; Ma, W.H.; He, Z.D.; Geng, C.; Chen, Z.J.; Wei, K.X.; Lei, Y.; Xie, K.Q. Simple and high-effective purification of metallurgical-grade silicon through Cu-catalyzed Chemical leaching. JOM 2018, 70, 2041-2047. [CrossRef]

20. Jiang, R.; Fruehan, R.J. Slag foaming in bath smelting. Metall. Trans. B 1991, 22, 481-489. [CrossRef]

21. Sheng, Z.; Zhang, Z.G.; Kang, W.L. Colloid and Surface Chemistry; Chemical Industry Press: Beijing, China, 2012.

22. Urbain, G. Viscosity estimation of slags. Steel Res. 1987, 58, 111-116. [CrossRef]

(C) 2019 by the authors. Licensee MDPI, Basel, Switzerland. This article is an open access article distributed under the terms and conditions of the Creative Commons Attribution (CC BY) license (http:/ / creativecommons.org/licenses/by/4.0/). 